\title{
Original
}

\section{Analysis of Factors Influencing the Dental Caries Prevalence in 7-Year-Old Chinese Children in Taiwan}

\author{
台湾 7 歳児の龄蝕有病に関わる要因の分析 \\ Yoshiko YAMAGUCHI* , Yoshihisa YAMASHITA*, \\ Ryuji SHIRAHAMA**, Akira SOGAME ${ }^{* * *}$, \\ Hideo MIYAZAKI* and Tadamichi TAKEHARA* \\ 山口佳子* ${ }^{*}$ 下喜 久* 白浜立二** \\ 十亀 輝 ${ }^{* * *}$ 宮 崎 秀 夫 ${ }^{*}$ 竹 原直 道 ${ }^{*}$
}

Received July 16, 1991 ; accepted August 29, 1991

\begin{abstract}
嫩要：台湾における触蝕有病に関わる要因を明らかにするために，台湾中部貣林市の7 歳の児童 112 名を対

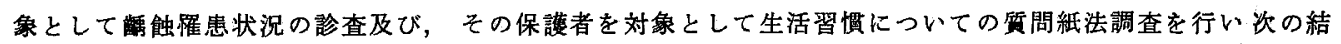
果を得た。1） $\mathrm{t}$ 検定を用いた解析の結果，歯磨きを低年龄から開始した児童ほど，また間食の頻度が少ない 児童ほど蝕が有意に少なかった。また，保讙者の歯科疾患に対する認狨が高い児童ほど有意に跑蝕が少な かった。2）数量化理論第 I 類を用いた解析の結果， 6 項目の重相関係数は $0.55 （ \mathrm{p}<0.01 ）$ であり，保護者 の歯科疾患に対する認識が児童の獻触の多塞に関与しており，保護者の歯科疾患に対する認識が高い児童ほ ど有意に䃌蝕が少なかった。また，歯磨きを低年龄から開始した児童ほど触蝕が有意に少なかった。以上か ら，母親の海科保健に対する意識が児童の年齡が低いときから確立されていることの重要性が示唆された。
\end{abstract}

Key words: Taiwan, Multivariate analysis, Toothbrushing habit

索引用語 : 台湾, 多変量解析, 歯磨き習慣

\section{Introduction}

The incidence of dental caries is influenced by many factors in a complex manner. Promotion of scientifically sound dental health activities and identification of the various factors influencing the inciden-

* Department of Preventive Dentistry, Kyushu Dental College (Chief: Prof. Tadamichi TAKEHARA)

* 九州歯科大学口腔衛生学教室 (主任 : 竹原直道教授)

** Nishi Public Health Center, Kumamoto City (Chief: Dr. Hiroshi OHTSUKA)

** 熊本市西保健所（主任 : 大塚博史所長）

*** Health and Environmental Department, Fukuoka Prefectural Government (Chief: Dr. Senjun TAIRA)

****福岡県保健環境部（主任：平良専純部長） 
ce of dental caries are required for the prevention of dental caries.

There have been many investigations concerning deciduous caries; and it is said that the prevalence of caries in deciduous dentition is influenced by the infants' developmental environment and habits of daily life $\mathrm{e}^{1-10)}$. However, there is little research concerning the prevalence of dental caries in school children ${ }^{11)}$. In 1987 we surveyed families in Taiwan concerning the children's daily habits and the degree to which dental diseases were recognized by their parents. We report the correlation between the prevalence of dental caries and the factors determining the presence of the disease.
Table 1 Mean number of df and DMF teeth in Chinese children in Taiwan

\begin{tabular}{rrcc}
\hline Age(yr.) & N & dft & DMFT \\
\hline 5 & 201 & $6.90 \pm 4.93$ & $0.06 \pm 0.41$ \\
6 & 121 & $6.94 \pm 4.40$ & $0.36 \pm 0.90$ \\
7 & 112 & $6.04 \pm 3.24$ & $1.63 \pm 1.56$ \\
8 & 97 & $5.20 \pm 3.20$ & $2.27 \pm 173$ \\
9 & 96 & $3.37 \pm 2.62$ & $2.88 \pm 2.00$ \\
10 & 105 & $1.55 \pm 2.04$ & $3.39 \pm 2.17$ \\
11 & 94 & $0.57 \pm 1.24$ & $3.67 \pm 3.00$ \\
12 & 18 & $0.11 \pm 0.32$ & $3.61 \pm 2.52$ \\
\hline & & & Mean \pm s.d.
\end{tabular}

\section{Materials and Methods}

A survey of dental caries and a questionnaire were carried out among 1,036 children (between 3 and 12 years of age) in Yuanlin City (population : 117,911), Taiwan in 1987. Of the 1,036 children surveyed, 112 seven-year-olds were selected for further analysis. Dental conditions were assessed with sufficient illumination using dental mirrors and probes. The questionnaire consisted of 20 items concerning the parents' recognition of dental diseases and the children's daily habits. The questionnaire was written in Chinese and answered by the parents.

The t-test was used for an analysis of significant differences in the prevalence of dental caries among each category in each item of the questionnaire.

The categories of the questionnaire items were quantitated by multivariant analysis using the type I theoretical quantification ${ }^{12)}$. Individual dental caries experience (DMFT $+\mathrm{dft}$ ) was used as a dependent variable.

\section{Result}

Table 1 shows the mean number of $\mathrm{df}$ and DMF teeth, and their standard deviation by age. The mean number of $\mathrm{df}$ teeth was 6.94 in 6-year-old children and decreased with age. The mean number of DMF teeth increased with age reaching 3.67 in 11-year-old children.

Table 2 shows the mean number of $\mathrm{DMF}+\mathrm{df}$ teeth in 7-year-old children by each category in 10 items, excluding questions concerning gingival diseases or questions which gave duplicate answers. The dental caries prevalence tended to be lower in children who had started brushing their teeth at a younger age. A particularly significant difference was found between children who had begun brushing their teeth at the age of 3 and those who had started at 6 or $7(\mathrm{p}<0.01,0.05)$. With respect to eating between meals, caries prevalence was significantly higher among those eating between meals on a daily basis than among those who did not $(p<0.01)$. Concerning the parents' knowledge of dental caries, children whose parents responded 'yes' to the question "Do you think dental caries is hereditary?" had significantly more caries than the children of parents responding with 'no' $(p<0.05)$. No significant differences were observed for items such as order of birth, frequency of toothbrushing, timing of toothbrushing, regularity of meals, type of snacks, or the frequency of consuming sweet drinks. 
Table 2 Factors which have an influence on the DMFT + dft in 7-year-old Chinese children

\begin{tabular}{|c|c|c|c|c|}
\hline Item & Category & $\mathrm{N}$ & $\frac{\text { Mean }}{\text { DMFT + dft }}$ & S. D. \\
\hline \multirow[t]{3}{*}{ Order of birth } & 1 & 43 & 8.53 & 3.77 \\
\hline & 2 & 35 & 6.06 & 3.51 \\
\hline & $3 \leqq$ & 24 & 8.08 & 4.22 \\
\hline \multirow[t]{2}{*}{ Sex } & Boy & 55 & 7.71 & 4.11 \\
\hline & Girl & 53 & 7.81 & 3.62 \\
\hline \multirow[t]{5}{*}{ Starting age of tooth brushing } & 3 yr. & 7 & $4.57-$ & 3.82 \\
\hline & $4 \mathrm{yr}$ & 22 & $\left.7.36\right|_{* *}$ & 3.35 \\
\hline & $5 \mathrm{yr}$. & 50 & $7.12^{* *} *$ & 4.16 \\
\hline & $6 \mathrm{yr}$. & 25 & $8.92-$ & 2.90 \\
\hline & $7 \mathrm{yr}$. & 5 & 10.40 & 4.28 \\
\hline \multirow[t]{3}{*}{ Frequency of brushing } & Once & 50 & 7.82 & 4.31 \\
\hline & Twice & 51 & 7.20 & 3.63 \\
\hline & $3 \leqq$ & 5 & 8.80 & 2.86 \\
\hline \multirow[t]{3}{*}{ Time for brushing } & Less than $2 \mathrm{~min}$. & 38 & 7.42 & 3.70 \\
\hline & $2 \min .<$ & 53 & 7.74 & 4.07 \\
\hline & $3 \min . \leqq$ & 20 & 7.90 & 3.86 \\
\hline \multirow[t]{2}{*}{ Regularity of meals } & Regular & 91 & 7.77 & 3.67 \\
\hline & Irregular & 19 & 7.11 & 4.93 \\
\hline \multirow[t]{3}{*}{ Snacks between meals } & Daily & 30 & $8.10^{-}$ & 3.67 \\
\hline & Sometimes & 78 & 7.64 ** & 3.99 \\
\hline & Seldom & 4 & $4.75^{-}$ & 0.96 \\
\hline \multirow[t]{2}{*}{ Kinds of snacks } & Sweet snacks & 80 & 8.05 & 3.74 \\
\hline & Others & 27 & 6.74 & 3.55 \\
\hline \multirow[t]{4}{*}{ Frequency of consuming sweet drinks } & Twice a day & 2 & 2.50 & 0.71 \\
\hline & Once a day & 25 & 7.80 & 3.71 \\
\hline & Sometimes & 59 & 8.46 & 3.73 \\
\hline & Never & 17 & 6.82 & 3.49 \\
\hline \multirow[t]{3}{*}{ Cause of dental caries } & Hereditary & 13 & $9.32^{-}$ & 2.98 \\
\hline & Acquired & 78 & $7.12-^{*}$ & 3.84 \\
\hline & Lack of understanding & 21 & 8.71 & 4.12 \\
\hline
\end{tabular}

The information shown in Table 2 for seven-year-old children was quantified by type I quantification and items closely related to dental caries prevalence were selected. Table 3 shows the items, categories, category scores, and the type II sum of square. A multiple correlation coefficient $R$ shows the degree of the explanatory variables upon the dependent variable. The multiple correlation coefficient of 6 items was $0.55(p<0.01)$. The type II sum of square indicates the degree of contribution of each item to the estimation of the dependent variable ${ }^{18)}$. The maximum value of type II SS for 'the cause of dental cari$e^{\prime}$ ' was $112.1(p<0.05)$. The 'starting age of tooth brushing' occupied the second and the 'frequency of consuming sweet drinks' the third rank. An intercategorical test revealed significant differences for the 
Table 3 Factors which have an influence on DMFT + dft and category score in 7-year-old Chinese children

\begin{tabular}{|c|c|c|c|}
\hline Item & Category & Category Score & Type II SS \\
\hline Starting age of tooth brushing & $\begin{array}{l}3 \mathrm{yr} . \\
4 \mathrm{yr} . \\
5 \mathrm{yr} . \\
6 \mathrm{yr} \\
7 \mathrm{yr}\end{array}$ & $\left.\left.\left.\begin{array}{c}5.31 \\
5.80 \\
6.01 \\
6.85 \\
12.30\end{array}\right] *\right] *{ }^{\prime}\right] *$ & 81.6 \\
\hline Regularity of meals & $\begin{array}{l}\text { Regular } \\
\text { Irregular }\end{array}$ & $\begin{array}{l}7.84 \\
6.66\end{array}$ & 13.2 \\
\hline Snacks between meals & $\begin{array}{l}\text { Daily } \\
\text { Sometimes } \\
\text { Seldom }\end{array}$ & $\begin{array}{l}8.51 \\
7.70 \\
5.55\end{array}$ & 23.0 \\
\hline Frequency of consuming sweet drinks & $\begin{array}{l}\text { Twice a day } \\
\text { Once a dey } \\
\text { Sometimes } \\
\text { Never }\end{array}$ & $\left.\begin{array}{l}\begin{array}{l}3.00- \\
8.80\end{array} \\
9.36 \\
7.84\end{array}\right] *$ & 79.4 \\
\hline Frequency of toothbrushing & $\begin{array}{l}\text { Once } \\
\text { Twice } \\
3 \text { times }\end{array}$ & $\begin{array}{l}7.69 \\
6.24 \\
7.84\end{array}$ & 41.7 \\
\hline Cause of dental caries & $\begin{array}{l}\text { Hereditary } \\
\text { Acquired } \\
\text { Lack of understanding }\end{array}$ & $\left.\begin{array}{l}7.44 \\
5.69- \\
8.64\end{array}\right] *$ & $112.1^{*}$ \\
\hline
\end{tabular}

Multiple correlation coefficient $0.55^{* *}$

${ }^{*} \mathrm{p}<0.05,{ }^{* *} \mathrm{p}<0.01$

'cause of dental caries', the 'starting age of tooth brushing' and the 'frequency of consuming sweet drinks' $(\mathrm{p}<0.05)$.

\section{Discussion}

The present study showed the dental caries prevalence of Taiwanese children between 5 and 12 years of age; the mean number of df teeth and DMF teeth was lower than those reported by the Ministry of Health and Welfare, Japan in 198714), except for DMFT in 8 and 9-year-old children.

Seven-year-old children were selected for further study because this age is an age when many deciduous teeth still remain and the first permanent molars are more likely to form caries.

The items of the questionnaire for which the t-test indicated significant intercategorical differences were the 'starting age of toothbrushing', 'snacks between meals' and the 'cause of dental caries'. A high prevalence of dental caries was observed among children who started brushing at a later age. No significant intercategorical differences were observed for other items related to toothbrushing such as 'frequency of toothbrushing' and 'time for toothbrushing'.

The prevalence of dental caries was significantly higher in children whose parents responded that caries is hereditary than in children whose parents believed that it is not. There was a higher prevalence of caries in those subjects having daily snacks than in those who did not. This fact coincides with other 
reports that the frequency of eating between meals significantly influences the prevalence of dental caries ${ }^{2,3)}$.

The results of a multivariant analysis using the type I theoretical quantification showed that the multiple correlation between six items was 0.55 . This is statistically significant. Among the various items only 'cause for dental caries' had a significant influence on the prevalence of caries. Significant intercategorical differences were observed for the items 'starting age of toothbrushing', 'frequency of consuming sweet drinks' and 'cause for dental caries'.

A review of prior studies revealed that most investigations ${ }^{1-11}$ did not recognize a correlation between caries of deciduous teeth and toothbrushing habits ${ }^{1-6)}$. For example there were reports stating that toothbrushing by children was not effective in preventing dental caries ${ }^{8,5,8)}$. However, these studies investigated only the present situation of habitual toothbrushing. Since dental caries is an accumulative disease, the actual correlation of toothbrushing to caries was considered to be difficult to determine ${ }^{9}$. Takahashi and Shimada ${ }^{9)}$ suggested that many children were motivated to brush daily after dental caries was diagnosed. The preventive effect of long-term daily toothbrushing by children who were caries-free was, therefore, undetected. In the present study we could not find any correlation between the 'frequency of toothbrushing' or ' time for toothbrushing' and the prevalence of caries, respectively. However, we found that early commencement of toothbrushing led to a lower prevalence of caries. Many reports state that caries prevalence is significantly lower in those who commenced toothbrushing at a lower age ${ }^{7-9)}$. Therefore, the question asking for the 'starting age of toothbrushing' is considered to represent the long-term dental health care habits rather than the present situation alone. Although the effect of toothbrushing on preventing dental caries is difficult to ascertain in a cross-sectional study, the present study revealed its efficacy beyond doubt.

The parents' ability to recognize dental diseases also influenced the dental caries prevalence in their children. Because children who started to brush their teeth at an earlier age had a lower prevalence of caries, the importance of establishing a consciousness of dental health care in mothers (fathers) was indicated.

\section{References}

1) Hinode, D., Shimada, J., Ohara, E., Terai, H., Yamasaki, T., Wada, A., Sagawa, H., Sato, M. and Nakamura, R.: Analysis of factors influencing the caries prevalence of deciduous teeth in children of three years old, J. Dent. Hlth, 38 ; 631-640, 1988, (in Japanese).

2) Sakuma, S., Takiguchi, T., Yagi, M., Tutui, S., Fukai, K., Sakai, O., Kobayashi, S., Koizumi, N. and Kifune, E.: A study of multiple factors influencing on the prevalence of dental caries of deciduous teeth in 3year-old children and the effectiveness of dental health education, J. Dent. Hlth, 37 ; 261-272, 1987, (in Japanese).

3) Sakuma, S. : Epidemiological study of dental caries prevalence in deciduous teeth: I. Analysis of factors influencing dental caries of 3.5 year-old children, J. Dent. Hlth, 40 ;
678-694, 1990, (in Japanese).

4) Savara, B. S. and Suher, T.: Dental caries in children one to six years of age as related to socioeconomic, food habits, and toothbrushing, J. Dent. Res., 34 ; 870-875, 1954.

5) Akizawa, Y., Hara, N. and Nagai, M. : Effects of intake of sweets, beverages and tooth brushing of tooth decay in infants, Japan. J. Pedodontics, 25 ; 323-331, 1987, (in Japanese).

6) Taura K. : Relationship between dental caries in deciduous teeth and tooth brushing in nursery school children, J. Dent. Hlth, 31 ; 174-187, 1981, (in Japanese).

7) Winter, G. B., Rule, D. C., Mailer, G. P. and Gordon, P. H.: The prevalence of dental caries in pre-school children aged 1 to 4 years, Brit. Dent. J., 130 ; 434-436, 1971.

8) Silver, D. H.: The prevalence of dental caries in 3-year-old children. Some social differences and a method of assessing pre-sch- 
ool needs at a local levels, Brit. Dent. J., 137 ; 123-128, 1984.

9) Takahashi, N. and Shimada, Y.: Relationship between toothbrushing and the prevalence of dental caries in 1 to 3 years old infants, J. Dent. Hlth, 33 ; 157-168, 1983, (in Japanese).

10) Tsukamoto, S.: An epidemiological study on dental caries prevalence of deciduous teeth -Examination by quantification type I-, J. Kyushu Dent. Soc., 35 ; 64-68, 1981, (in Japanese).

11) Kawaguchi, T.: An epidemiological study on dental caries prevalence of permanent teeth in school children -Examination by quan- tification type I and II-, J. Kyushu Dent. Soc., 39 ; 638-662, (in Japanese).

12) Komazawa, T.: The quantification theory and data processing, Asakura Publishing Company, Tokyo, 1989, p10-16, (in Japanese).

13) Takahashi, I., Ohashi, Y. and Haga, T.: Analysis of experimental data using SAS, University of Tokyo Press, Tokyo, 1989, p. 214, (in Japanese).

14) Dental Health Division of Health Policy Bureau Ministry of Health and Welfare Japan : Report on the survey of dental diseases (1987), Oral Health Association, Tokyo, 1989, p.58, 107, (in Japanese). 